\section{Mineral Composition of Native and Introduced Clovers ${ }^{1}$}

\author{
JOHN W. HAMILTON AND CARL S. GILBERT2 \\ Professor and Professor Emeritus, Division of Biochemistry, \\ University of Wyoming, Laramie.
}

\section{Highlight}

Samples of seven native and four introduced clovers were collected from widely scattered areas in Wyoming and southern Montana. Most of the samples were collected at bloom stage during two successive growing seasons. The levels of calcium, phosphorus, magnesium, sodium, potassium, sulfur, colbalt, copper, iron, manganese, molybdenum and zinc in these plants were measured. Levels of calcium were fairly high and extremely variable, ranging from 1.12 to $5.74 \%$. Magnesium contents were quite variable with a range of 0.22 to $0.97 \%$. Considerable variation in the levels of cobalt, range 0.09 to $1.75 \mathrm{ppm}$, exists and there were indications of species differences in accumulating ability under identical conditions. Copper accumulating capacity apparently varies from species to species and appears to be in direct contrast to cobalt accumulating ability. The range of copper was 7.0 to $49.5 \mathrm{ppm}$. Iron varied over a wide range with some unexpected high values. The levels of iron varied from 222 to $3329 \mathrm{ppm}$. Contents of manganese ranged from 39 to $250 \mathrm{ppm}$ with higher levels being found in samples of alsike and white clover from the mud volcano areas of Yellowstone National Park. Amounts of mineral elements present in the clover samples were high enough to provide an adequate plane of nutrition for consuming livestock and wild game.

Clovers are important forage plants in Wyoming as well as other western states. In most of the west

${ }^{1}$ Published with the approval of the Director, Wyoming Agricultural Experiment Station, as Journal Paper No. 427. Received May 26, 1970; accepted for publication September 2, 1970.

2 Deceased. clovers grow on the range and also on cultivated areas. Extensive travel and careful observation of Wyoming and several areas of other western states indicates the widespread distribution of certain species of native clovers. These clovers appear capable of making adaptations to varying conditions such as soil type, elevation, moisture supply, length of growing season, and grazing pressures. Three species of native clovers collected in this study were located on limited acreage in one or at most a few sites in Wyoming and apparently require certain specific conditions and seem to tolerate only slight deviations from the optimum. Native clovers are extremely variable in appearance and growth habits and may grow where one would least expect to find them. The cultivated clovers are scattered throughout the western states on cultivated areas as well as on many areas where they have escaped from cultivation. The clovers are rated as valuable plants by livestock producers and gamc management personnel and knowledge of their mineral composition will be of considerable value.

\section{Review of Literature}

A rather detailed description of the appearance, collection sites, growth habits, and preferred habitat for certain native clovers was presented by Hamilton (1961). The appearance and growth habits of the introduced clovers are familiar and will not be discussed. The common names used are those proposed by Kelsey and Dayton (1942) and 
Beetle (1970). Personal observations as well as study of numerous botany books and records of collection sites of herbarium specimens has indicated that the native clovers, i.e., whiproot (Trifolium dasyphyllum), hollyleaf ( $T$. gymnocarpon), longstalk ( $T$. longipes), and Parry ( $T$. parry $i$ ) are widely scattered throughout Wyoming and many western states. The other native clovers collected, i.e., Andean (T. andinum), Hayden ( $T$. haydeni) and dwarf ( $T$. nanum) occur on small isolated areas and on a limited number of sites. The proximate analyses, carotene content, levels of calcium, phosphorus and magnesium for many of the native clovers were reported by Hamilton (1961). The comparative mineral composition of samples of alsike and longstalk clovers collected from identical or similar sites was reported by Hamilton and Gilbert (1968). The proximate analyses of alsike, red, strawberry and white clovers can be easily found in the literature and is not reported here. The National Research Council (1963 and 1968) published recommended dietary levels of mineral elements for adequate nutrition of cattle and sheep. The mean mineral composition of clovers and other livestock forage has been compiled by Morrison (1959) and National Research Council (1964). To our knowledge, no detailed published data are available concerning the mineral composition of these native clovers. The literature contains innumerable studies of the mineral plant composition of cultivated clovers and soil treatments that influcnce plant composition. Jordan (1955) reported the mineral composition of ladino, red ( $T$. pratense) and alsike clovers ( $T$. hybridum) from several Idaho countics. Ccrtain pertinent references regarding clover composition will be cited in the discussion section.

\section{Methods and Procedures}

Most of the clovers were collected at bloom stage from various growing sites in Wyoming and along the southern boundary of Montana. A limited number of early season native clovers were collected at late bloom or seed stage because of travel schedules. The samples were collected from the same site generally during each of two, and, occasionally three, successive growing seasons. The native clovers collected were: Andean, whiproot, hollyleaf, Hayden, longstalk, dwarf and Parry. The following introduced clovers were collected: strawberry $(T$, fragiferum), alsike, red and white ( $T$. repens). The freshly collected samples were hand-picked to insure uniformity, washed in distilled water and air dried. The dry samples were ground to pass through the 40 mesh stainless steel coated brass screen of a Wiley mill. Moisture, calcium, phosphorus, magnesium, sulfur, cobalt, copper, iron, manganese and zinc analyses were made using AOAC (1960) methods. Molybdenum, sodium and potassium were determined using the methods of Parks et al. (1943) with slight modifications.

A limited number of unground and ground samples were analyzed under nearly identical conditions. Slightly higher values for the levels of iron, copper, and manganese were obtained for the Wiley mill ground samples; however, the differences were not of sufficient magnitude to markedly change the values obtained. Most values reported are the average of duplicate analyses of each of two successive yearly samples. Mean values for all analyses of each species are reported. The range of concentrations for each sample is shown except where less than four samples were available.

\section{Results and Discussion}

The common name, number of samples analyzed, mean values of each group of samples and the range of sample contents of twelve mineral elements are reported in Table 1. Since some samples of hollyleaf clover were collected at bloom stage and some samples collected at late bloom or seed stage the results are reported for each stage of growth.
The calcium content of several species of the native clovers, i.e., Andean, dwarf, Hayden, hollyleaf, and Parry exhibit mean values ranging from appreciably higher to nearly two times the mean calcium contents of the remaining native and introduced clovers. The individual calcium contents of hollyleaf and Parry samples were extremely variable: 1.95 to $5.74 \%$. Soil characteristics were apparently such that the calcium contents of certain samples of clovers, regardless of species, was considerably higher than that of comparable samples collected from other locations. This is apparent in the case of Andean and hollyleaf clovers collected from an identical site in southwestern Wyoming and whiproot and Parry clovers collected from two identical sites in the Snowy Range Mountains of southern Wyoming. The calcium levels of whiproot clover, while high for this species, were considerably lower than the levels present in Parry clover from the same site, i.e., 2.49, $3.82 ; 3.14,3.70 \%$ respectively. In general the mean levels and range of calcium values for longstalk clover and the introduced clovers were of comparable magnitude from all sites. The overall similar mineral composition of longstalk and alsike clovers was previously emphasized by Hamilton and Gilbert (1968). Jordan (1955) reported a mean calcium content of $1.21 \%$ for red clover as compared to $1.99 \%$ for the samples analyzed in this study.

Phosphorus levels in these clovers exhibit a narrow range from 0.22 to $0.48 \%$. The mean phosphorus values of the clovers analyzed appear to be adequate to meet the National Research Council (1963, 1968) recommended levels for lactating cows and ewes.

Magnesium levels were quite variable, ranging from 0.22 to $0.97 \%$, with most values falling within a narrower range of 0.36 to $0.50 \%$. However, samples of whiproot and Parry clovers growing on soils derived from dolomite contained magnesium mean values of 0.80 and $0.95 \%$ respectively. The National 
Table 1. Common name, number of samples analyzed, and mineral composition of native and introduced clovers. ${ }^{1}$

\begin{tabular}{|c|c|c|c|c|c|c|c|c|c|c|c|c|c|c|}
\hline $\begin{array}{l}\text { Common } \\
\text { Name }\end{array}$ & $\begin{array}{l}\text { Range } \\
\text { Mean }\end{array}$ & $\begin{array}{l}\text { No. of } \\
\text { Samples }\end{array}$ & $\begin{array}{c}\mathrm{Ca} \\
\%\end{array}$ & $\begin{array}{l}\mathrm{P} \\
\%\end{array}$ & $\begin{array}{r}\mathrm{Mg} \\
\%\end{array}$ & $\begin{array}{r}\mathrm{Na} \\
\%\end{array}$ & $\begin{array}{l}\mathrm{K} \\
\%\end{array}$ & $\begin{array}{l}\mathrm{S} \\
\%\end{array}$ & $\begin{array}{r}\text { Co } \\
\mathrm{ppm}\end{array}$ & $\begin{array}{r}\mathrm{Cu} \\
\mathrm{ppm}\end{array}$ & $\begin{array}{r}\mathrm{Fe} \\
\mathrm{ppm}\end{array}$ & $\begin{array}{r}\mathrm{Mn} \\
\mathrm{ppm}\end{array}$ & $\begin{array}{r}\text { Mo } \\
\text { ppm }\end{array}$ & $\begin{array}{r}\mathrm{Zn} \\
\mathrm{ppm}\end{array}$ \\
\hline \multicolumn{15}{|c|}{ Native Clovers } \\
\hline Andean $^{2}$ & Mean & 2 & 3.84 & 0.22 & 0.47 & 0.20 & 1.65 & 0.48 & 1.03 & 11.4 & 1299 & 112 & 3.21 & 47.0 \\
\hline Dwarf & Mean & 3 & 3.31 & 0.27 & 0.70 & 0.15 & 2.08 & 0.51 & 0.45 & 12.7 & 556 & 109 & 1.47 & 39.2 \\
\hline Hayden & Mean & 3 & 2.99 & 0.33 & 0.54 & 0.13 & 2.02 & 0.50 & 0.49 & 15.2 & 759 & 72 & 2.21 & 35.1 \\
\hline Hollyleaf ${ }^{2}$ & Mean & 13 & 3.42 & 0.34 & 0.48 & 0.13 & 2.17 & 0.55 & 0.30 & 25.5 & 805 & 107 & 3.38 & 15.2 \\
\hline Holzyzeaf ${ }^{2}$ & Range & 13 & $\begin{array}{l}2.72 \\
4.80\end{array}$ & $\begin{array}{l}0.29 \\
0.42\end{array}$ & $\begin{array}{l}0.31 \\
0.70\end{array}$ & $\begin{array}{l}0.09 \\
0.25\end{array}$ & $\begin{array}{l}1.74 \\
3.49\end{array}$ & $\begin{array}{l}0.32 \\
0.80\end{array}$ & $\begin{array}{l}0.13 \\
0.54\end{array}$ & $\begin{array}{l}16.7 \\
38.6\end{array}$ & $\begin{array}{r}643 \\
1093\end{array}$ & $\begin{array}{r}87 \\
156\end{array}$ & $\begin{array}{l}1.59 \\
6.59\end{array}$ & $\begin{array}{r}7.1 \\
26.4\end{array}$ \\
\hline Hollyleaf & Mean & 7 & 2.64 & 0.33 & 0.49 & 0.19 & 2.37 & 0.38 & 0.34 & 24.2 & 869 & 93 & 2.72 & 21.7 \\
\hline Holzyleaf & Range & $7^{\prime}$ & $\begin{array}{l}2.32 \\
3.35\end{array}$ & $\begin{array}{l}0.29 \\
0.48\end{array}$ & $\begin{array}{l}0.37 \\
0.64\end{array}$ & $\begin{array}{l}0.14 \\
0.27\end{array}$ & $\begin{array}{l}1.67 \\
3.43\end{array}$ & $\begin{array}{l}0.24 \\
0.56\end{array}$ & $\begin{array}{l}0.17 \\
0.52\end{array}$ & $\begin{array}{l}18.6 \\
37.1\end{array}$ & $\begin{array}{r}682 \\
1111\end{array}$ & $\begin{array}{r}78 \\
131\end{array}$ & $\begin{array}{l}1.89 \\
4.08\end{array}$ & $\begin{array}{l}19.6 \\
27.1\end{array}$ \\
\hline Longstalk & Mean & 5 & 1.66 & 0.38 & 0.47 & 0.22 & 2.69 & 0.44 & 0.63 & 29.9 & 836 & 69 & 4.56 & 23.5 \\
\hline Longstalk & Range & 5 & $\begin{array}{l}1.51 \\
2.08\end{array}$ & $\begin{array}{l}0.37 \\
0.42\end{array}$ & $\begin{array}{l}0.36 \\
0.54\end{array}$ & $\begin{array}{l}0.11 \\
0.29\end{array}$ & $\begin{array}{l}1.82 \\
4.01\end{array}$ & $\begin{array}{l}0.19 \\
0.76\end{array}$ & $\begin{array}{l}0.23 \\
1.52\end{array}$ & $\begin{array}{l}10.8 \\
49.5\end{array}$ & $\begin{array}{r}385 \\
1575\end{array}$ & $\begin{array}{l}53 \\
87\end{array}$ & $\begin{array}{l}3.00 \\
6.80\end{array}$ & $\begin{array}{l}18.7 \\
30.8\end{array}$ \\
\hline Parry & Mean & 11 & 3.54 & 0.33 & 0.70 & 0.17 & 2.07 & 0.39 & 0.53 & 19.4 & 420 & 109 & 2.20 & 34.8 \\
\hline Parry & Range & 11 & $\begin{array}{l}1.95 \\
5.74\end{array}$ & $\begin{array}{l}0.28 \\
0.39\end{array}$ & $\begin{array}{l}0.41 \\
0.97\end{array}$ & $\begin{array}{l}0.14 \\
0.23\end{array}$ & $\begin{array}{l}1.39 \\
2.99\end{array}$ & $\begin{array}{l}0.25 \\
0.59\end{array}$ & $\begin{array}{l}0.14 \\
1.21\end{array}$ & $\begin{array}{l}17.3 \\
36.3\end{array}$ & $\begin{array}{l}280 \\
652\end{array}$ & $\begin{array}{r}67 \\
175\end{array}$ & $\begin{array}{l}1.78 \\
2.80\end{array}$ & $\begin{array}{l}75.4 \\
55.8\end{array}$ \\
\hline Whiproot & Mean & 16 & 2.02 & 0.31 & 0.46 & 0.14 & 1.92 & 0.46 & 0.81 & 14.3 & 1123 & 97 & 2.03 & 29.7 \\
\hline Whiproot & Range & 16 & $\begin{array}{l}1.31 \\
3.22\end{array}$ & $\begin{array}{l}0.27 \\
0.38\end{array}$ & $\begin{array}{l}0.22 \\
0.80\end{array}$ & $\begin{array}{l}0.12 \\
0.17\end{array}$ & $\begin{array}{l}1.02 \\
2.62\end{array}$ & $\begin{array}{l}0.27 \\
0.81\end{array}$ & $\begin{array}{l}0.35 \\
1.75\end{array}$ & $\begin{array}{l}10.2 \\
21.2\end{array}$ & $\begin{array}{r}382 \\
1943\end{array}$ & $\begin{array}{r}70 \\
145\end{array}$ & $\begin{array}{l}1.30 \\
2.90\end{array}$ & $\begin{array}{l}19.5 \\
41.4\end{array}$ \\
\hline \multicolumn{15}{|c|}{ Introduced Clovers } \\
\hline Alsike & Mean & 12 & 1.70 & 0.35 & 0.45 & 0.15 & 2.77 & 0.35 & 0.47 & 13.7 & 952 & 115 & 2.45 & 24.5 \\
\hline Alsike & Range & 12 & $\begin{array}{l}1.24 \\
2.03\end{array}$ & $\begin{array}{l}0.32 \\
0.45\end{array}$ & $\begin{array}{l}0.31 \\
0.67\end{array}$ & $\begin{array}{l}0.09 \\
0.26\end{array}$ & $\begin{array}{l}1.83 \\
3.46\end{array}$ & $\begin{array}{l}0.19 \\
0.70\end{array}$ & $\begin{array}{l}0.17 \\
1.24\end{array}$ & $\begin{array}{l}10.1 \\
26.6\end{array}$ & $\begin{array}{r}272 \\
3329\end{array}$ & $\begin{array}{r}70 \\
245\end{array}$ & $\begin{array}{l}1.74 \\
3.63\end{array}$ & $\begin{array}{l}75.8 \\
40.6\end{array}$ \\
\hline Red & Mean & 2 & 1.99 & 0.25 & 0.47 & 0.16 & 2.07 & 0.21 & 0.47 & 20.6 & 565 & 47 & 2.59 & 18.3 \\
\hline Strawberry & Mean & 2 & 1.90 & 0.26 & 0.29 & 0.21 & 2.48 & 0.58 & 0.33 & 7.2 & 937 & 53 & 2.55 & 29.8 \\
\hline White & Mean & 13 & 1.67 & 0.37 & 0.42 & 0.19 & 2.97 & 0.33 & 0.22 & 17.3 & 560 & 121 & 2.89 & 30.5 \\
\hline White & Range & 13 & $\begin{array}{l}1.12 \\
2.22\end{array}$ & $\begin{array}{l}0.32 \\
0.43\end{array}$ & $\begin{array}{l}0.35 \\
0.58\end{array}$ & $\begin{array}{l}0.11 \\
0.40\end{array}$ & $\begin{array}{l}2.67 \\
4.12\end{array}$ & $\begin{array}{l}0.86 \\
0.51\end{array}$ & $\begin{array}{l}0.09 \\
0.73\end{array}$ & $\begin{array}{l}71.5 \\
23.8\end{array}$ & $\begin{array}{l}222 \\
927\end{array}$ & $\begin{array}{r}72 \\
250\end{array}$ & $\begin{array}{l}2.05 \\
4.83\end{array}$ & $\begin{array}{l}16.4 \\
44.6\end{array}$ \\
\hline
\end{tabular}

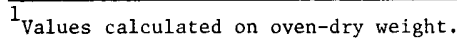

${ }^{2}$ Seed stage. All others bloom stage.

Research Council (1964) reports mean magnesium values of 0.32 , 0.45 , and $0.32 \%$ for alsike, red, and white clovers, respectively, as compared to values of $0.45,0.47$, and $0.42 \%$ found in this study. Svanberg and Ekman (1946) reported somewhat lower mean magnesium levels of 0.34 and $0.32 \%$ for samples of red and alsike clovers grown in Sweden.

The mean sodium levels in the samples varied within rather narrow limits of 0.13 to $0.22 \%$. Only a few individual sample values were outside this range. Potassium levels present on the other hand are quite variable ranging from 1.02 to $4.12 \%$. The mean levels of potassium found in the introduced clover samples compare favorably with mean values reported by the National Research Council (1964).

The level of sulfur present in the clover samples analyzed ranged from 0.19 to $0.81 \%$. In most instances the sulfur values found in this study are considerably higher than levels of
0.19 and $0.14 \%$ for air-dry alsike and red clover hays reported by Morrison (1959).

The cobalt contents of the native and introduced clover samples are in general higher than anticipated and extremely variable. The range of cobalt levels is 0.09 to $1.75 \mathrm{ppm}$ with most samples falling within the 0.20 to $1.00 \mathrm{ppm}$ range. The species of introduced clovers had lower mean values with a range of 0.22 to $0.47 \mathrm{ppm}$, than did most of the native clovers. It appears that a special variation exists in the ability to accumulate cobalt since Andean and hollyleaf samples collected at the same time, from the same site and at similar stages of growth contained cobalt mean values of 1.03 and 0.22 ppm respectively. Hill et al. (1953) reported low (0.04), average (0.14) and high (0.31) ppm levels of cobalt in red clover plants growing on different New Jersey soils. This compares with a mean value of $0.47 \mathrm{ppm}$ co- balt for the red clover samples reported here. On nearly all ranges clovers provide only a fraction of the total daily intake of forage and even though the cobalt levels present in some of the clovers were quite high, cobalt toxicity problems would not be anticipated. Underwood (1962) reports that a very wide margin of safety exists between the quantities of cobalt necessary to fulfill the nutritional requirements of sheep and cattle and the toxic limits. The minimal dietary requirements according to the National Research Council $(1963,1968)$ are 0.07 ppm cobalt for sheep and cattle.

Sample levels of copper exhibited a rather wide range, 7.0 to $49.5 \mathrm{ppm}$ with a range of mean values of 7.2 to $29.9 \mathrm{ppm}$. Andean and hollyleaf clovers collected from the same site in southwestern Wyoming as mentioned above had mean values of 11.4 and $34.0 \mathrm{ppm}$ which is in direct contrast to the levels of cobalt present in these samples. The National 
Research Council (1964) reports copper levels of $11.9 \mathrm{ppm}$ for white clover, $15.0 \mathrm{ppm}$ for red clover and $6.0 \mathrm{ppm}$ for alsike as compared to values of 17.3, 20.6 and $13.7 \mathrm{ppm}$ respectively for these species analyzed in the present study.

The iron contents of the clovers were extremely variable with some unexpectedly high values. Iron uptake of plants is apparently influenced by many factors other than species and varietal differences. The iron levels in the clover samples varied from 222 to $3329 \mathrm{ppm}$. Andean had a high mean level of 1299 as compared to $761 \mathrm{ppm}$ for hollyleaf from the same area. The two samples of alsike clover growing on a red soil in southern Wyoming had a mean content of 3278 ppm of iron. Whiproot samples collected at an elevation of 11,700 feet had a mean iron value of 1023 as compared to $643 \mathrm{ppm}$ of iron for Parry clover collected from the same site. The soil of this site had a pH of 5.4. On other common growing sites the mean iron values for Parry and whiproot clovers were: 256 and 950; 298 and 1045; 321 and 506 ppm respectively. Other samples of clovers collected from identical sites exhibited species differences in their ability to accumulate iron.

The mean manganese levels varied from 47 to $121 \mathrm{ppm}$ with individual sample values of 39 to 250 ppm. While the manganese levels were extremely variable, no species differences were noted. The highest manganese contents were 245 and $250 \mathrm{ppm}$ found in alsike and white clovers collected at the Mud Volcano area in Yellowstone National Park. The manganese content of the soil was $159 \mathrm{ppm}$, and the $\mathrm{pH}$ of the soil of this site was 4.2, the lowest of any collection area. White clover collected in Norris Geyser Basin, another thermal area of Yellowstone National Park, had a manganese content of $227 \mathrm{ppm}$ in soil containing 307 ppm of manganese and a pH of 4.3. Alsike and white clover samples growing on soil with 1537 ppm of manganese and a $\mathrm{pH}$ of 6.4 had manganese levels of 75 and 95 ppm, respectively. Kurmies and Zezschwit (1952) found no relationship between the manganese content of hay and the amount present in the soil. They found that plants from neutral or alkaline soils had the lowest and those grown on acid soils the highest manganese content. Our results in general corroborate their findings.

The molybdenum contents of the samples varied from 1.30 to 6.80 ppm. Longstalk, hollyleaf (seed stage) and Andean had the highest mean values of 4.56, 3.38 and 3.21 ppm, respectively. The soil from which the Andean and hollyleaf clover (seed stage) was collected had mean values of $4.27 \mathrm{ppm}$ of molybdenum and a $\mathrm{pH}$ of 8.1. The hollyleaf clover (seed stage) collected from another area had a mean molybdenum content of $6.24 \mathrm{ppm}$ and the soil had a $\mathrm{pH}$ of 8.2. The mean molybdenum contents of $2.89 \mathrm{ppm}$ for white clover and $2.45 \mathrm{ppm}$ for alsike clover and $2.55 \mathrm{ppm}$ for strawberry clover compare to ranges of values of 3-5 and 4-5 ppm molybdenum reported by Barshad (1948). Barshad found soil molybdenum contents of 0.5 to 10.0 ppm of which about $60 \%$ was water soluble and available in soils of $\mathrm{pH}$ 8.0. He found that young plants were more toxic to cattle even though the molybdenum content of the plants increased with age. His research indicated that cattle suffered no toxic effects unless the molybdenum level was above $10 \mathrm{ppm}$. All of the clovers in the present study, while carrying higher than anticipated molybdenum levels could be safely consumed by both cattlc and sheep.

Zinc content was fairly high and not extremely variable with an overall range of 7.1 to $55.8 \mathrm{ppm}$. Andean had the highest mean level of 47.0; with lower values in dwarf, 39.2; Hayden, 35.1; and Parry, 34.8 ppm of zinc. The mean values for Hayden and Parry clovers were quite high. The individual samples were extremely variable indicating non-species factors such as level of soil zinc, soil $\mathrm{pH}$, presence of other elements, and other factors that may influence uptake of zinc. The National Research Council (1964) reports mean zinc levels of 60.2 in alsike and $17.2 \mathrm{ppm}$ in red clover as compared to mean levels of 24.5 and $18.3 \mathrm{ppm}$ respectively in similar samples of this study.

Our study of the mineral composition of certain native and introduced clovers indicates the wide variability in the levels of mineral elements accumulated. Samples of all species contain sufficient levels to render them nutritionally excellent forages for sheep, cattle and game animals. Their overall proximate analyses along with their mineral composition, relative abundance, high level of digestibility, and high palatability make them extremely valuable range plants. Livestock men should strive to increase the carrying capacity of their ranges by seeding, soil treatment, water conservation, controlled grazing, and other practices to increase the production of both native and introduced clovers.

\section{Literature Cited}

Association of Official Agricultural Chemists. 1960. Official methods of analysis. 9th Ed. Association of Official Agricultural Chemists, Washington, D. C. 832 p.

BARSHAD, IsAaC. 1948. Molybdenum content of pasture plants in relation to toxicity to cattle. Soil Sci. 66: 187-195.

Beetr.e, Alan A. 1970. Recommended plant names. Wyo. Agr. Exp. Sta. Res. J. 31. 124 p.

Hamilton, John W. 1961. Native clovers and their chemical composition. J. Range Manage. 14:327-331.

Hamilton, John W., and Carl S. GilBERT. 1968. Comparative mineral composition of longstalk and alsike clovers. J. Range Manage. 21:53-55.

Hill, A. C., S. J. Toth, ANd F. E. Bear. 1953. Cobalt in New Jersey soils and plants. Soil Sci. 76:273-284.

Jordan, J. V. 1955. Protein and mineral content of forage, legumes and grasses in Idaho. Idaho Agr. Exp. Sta. Bull. 245. 7 p.

Kelsey, Harlan P., and William A. DAyton. 1942. Standardized plant names. 2nd Ed. J. Horace McFarland Co., Harrisburg, Pennsylvania. 675 p. 
Kurmies, B., and E. V. Zezschwit. 1952. Studies on the manganese content of meadow hay. Phosphorsäure 12:238-49.

Morrison, F. B. 1959. Feeds and Feeding, a handbook for the student and stockman. 22nd Ed. The Morrison Publishing Co., Clinton, Iowa. $1207 \mathrm{p}$.

National Academy of Sciences-National Research Council. Subcommittee on Bcef Cattle Nutrition, Committee on Animal Nutrition.
1963. IV. Nutrient requirements of beef cattle. Publ. 1137, 30 p.

National Academy of Sciences-National Research Council. 1964. Joint United States-Canadian tables of feed composition. Publ. 1232, $167 \mathrm{p}$.

National Academy of Sciences-National Research Council. Subcommittee on Sheep Nutrition. 1968. Nutrient requirements of sheep. Publ. 1693, 64 p.
Parks, R. Q., S. L. Hood, C. Hurwitz, AND G. H. Ellis. 1943. Quantitative chemical microdetermination of twelve elements in plant tissue. Ind. and Eng. Chem. Anal. Ed. 15:527-33. Svanberg, Olaf, and Per Ekman. 1946. Magnesium in the vegetation from Swedish soils. Kgl. Lantbruksakad. Tid. 85:54-99.

Underwood, E. J. 1962. Trace elements in human and animal nutrilion. 2nd Ed. Academic Press, New York, N. Y. 429 p. 